\title{
СЕТЕВЫЕ ТЕХНОЛОГИИ КАК СРЕДСТВО ФОРМИРОВАНИЯ ИНФОРМАЦИОННОЙ КОМПЕТЕНТНОСТИ В КУРСЕ ИНФОРМАТИКИ ОСНОВНОЙ ШКОЛЫ
}

\author{
Рихтер Т.В., Краснов М.Д.
}

Пермский государственный национальный исследовательский университет, г. Соликамск, Пермский край, Российская Федерация

В статье рассмотрена сущность информационной компетентности школьников, выделены ее структурные компоненты-умения, выявлены сетевые технологии, влияющие на их формирование при обучении школьному курсу информатики.

Ключевые слова: информачионная компетентность; сетевые технологии; структурные компоненты-умения информационной компетентности; школьный курс информатики.

\section{NETWORK TECHNOLOGIES AS A MEANS OF BUILDING INFORMATION COMPETENCE IN THE COURSE OF INFORMATICS OF PRIMARY SCHOOL}

\section{Richter T.V., Krasnov M.D.}

Perm State University, Solikamsk, Perm Region, Russian Federation

The article examines the essence of the information competence of schoolchildren, highlights its structural components-skills, identifies network technologies that influence their formation when teaching a school course of informatics.

Keywords: information competence; network technologies; structural components-skills of information competence; school course of informatics. 


\section{Введение}

В соответствии с ФГОС среднего общего образования один из метапредметных результатов освоения основной общеобразовательной программы заключается в готовности и способности к самостоятельной информационно-познавательной деятельности школьников, умении ориентироваться в различных источниках информации, оценивать и интерпретировать ее [1], что указывает на необходимость формирования информационной компетентности.

Цель исследования: выявить сетевые технологии, влияющие на структурные компоненты-умения информационной компетентности школьников при обучении информатике.

\section{Материалы и методы исследования}

Ведущими методами исследования явились обобщение и анализ научных трудов по теме исследования.

\section{Результаты исследования и их обсуждение}

А.В. Лукьянова под информационной компетентностью понимает свойство личности, которое состоит из знаний, умений, навыков, опыта, полученных при обучении и самообучении информационным технологиям. Автор выделяет в ее структуре следующие компоненты: когнитивный и деятельностный (мотивационный, поведенческий, ценностно-смысловой, эмоционально-волевой) [1, с. 97].

Анализ научной литературы (М.М. Жигатова, А.В. Лукьянова, С.В. Олефир, А.В. Рогожина, А.М. Рычкова и др.) позволил выделить в структуре информационной компетентности при обучении информатики в школе следующие компоненты и входящие в их состав умения: ценностно-мотивационный (готовность к саморазвитию в сфере информационных технологий, построение индивидуальной образовательной траектории обучения информатике); когнтитивный (знание устройств компьютера, умение работать с программным обеспечением); коммуникативный (коммуникационные взаимодействия); деятельностный (отбор, усвоение, переработка, трансформация и генерирование информации); технико-технологический (использование 
современных информационных и коммуникационных технологий для работы с информацией); оценочно-рефлексивный (рефлексия, самоанализ); коррекционный (коррекция результатов деятельности по овладению школьным курсом информатики).

Информационная компетентность может формироваться с помощью различных средств, например, через некорректные задачи [3]. Однако, эффективным инструментарием формирования информационной компетентности в курсе информатики основной школы является использование сетевых технологий: электронной почты, онлайн-тестов, облачных и дистанционных технологий, квестов, блогов, глогов, сайтов, «сервисов Web 2.0», Classroom от Google и др.

При организации системы дистанционного обучения информатике возможно применение двух моделей: одноуровневой и двухуровневой [2, с. 207].

Анализ педагогической литературы по проблеме исследования позволил выделить сетевые технологии, способствующие формированию умений информационной компетентности в курсе информатики основной школы (таблица 1).

Таблица 1 .

Сетевые технологии, способствующие формированию структурных компонент информационной компетентности

\begin{tabular}{|l|l|}
\hline \multicolumn{1}{|c|}{ Структурные компоненты } & \multicolumn{1}{c|}{ Сетевые технологии } \\
\hline ценностно-мотивационный & социальные сети \\
\hline когнтитивный & $\begin{array}{l}\text { дистанционные технологии, обучающие сайты, } \\
\text { квесты }\end{array}$ \\
\hline коммуникативный & социальные сети, электронная почта \\
\hline деятельностный & $\begin{array}{l}\text { вики, блоги, глоги, поисковые сферы, карты, } \\
\text { логосферы облака сервисов }\end{array}$ \\
\hline технико-технологический & Сlassroom от Google \\
\hline оценочно-рефлексивный & $\begin{array}{l}\text { онлайн-тесты и другие различные контрольно- } \\
\text { измерительные материалы }\end{array}$ \\
\hline коррекционный & дистанционные технологии \\
\hline
\end{tabular}

\section{Заключение (выводы)}

Использование выделенных сетевых технологий в курсе информатики основной школы будут способствовать формированию уме- 
ний информационной компетентности и повышению качественного уровня образовательного процесса.

\section{Список литературы}

1. Лукьянова А.В. Особенности формирования информационной компетентности на этапе школьного образования // Ярославский педагогический вестник. 2014. Том 2. № 2. С. 95-99.

2. Рихтер Т.В. Модель системы дидактического обеспечения дистанционного обучения информатике педагогических вузов // Возможности образовательной области «Математика и информатика» для реализации компетентностного подхода в школе и вузе: материалы Международной научно-практической конференции. Соликамск: СГПИ, 2012. С. 200-207.

3. Bezusova T.A., Richter T.V., Sugrobova N.Yu., Chugainova L.V., Shestakova L.G. Ill-Posed Problems as a Means of Information Competence Development // Espacios. 2018. Vol. 39 (Number 33). C. 26.

\section{References}

1. Luk'yanova A.V. Osobennosti formirovaniya informatsionnoy kom-petentnosti na etape shkol'nogo obrazovaniya // Yaroslavskiy pedagogicheskiy vestnik. 2014. Tom 2. № 2. S. 95-99.

2. Rikhter T.V. Model' sistemy didakticheskogo obespecheniya distantsionnogo obucheniya informatike pedagogicheskikh vuzov // Vozmozhnosti obrazovatel'noy oblasti «Matematika i informatika» dlya realizatsii kompetent-nostnogo podkhoda v shkole i vuze: materialy Mezhdunarodnoy nauchno-prakticheskoy konferentsii. Solikamsk: SGPI, 2012. S. 200-207.

3. Bezusova T.A., Richter T.V., Sugrobova N.Yu., Chugainova L.V., Shestakova L.G. Ill-Posed Problems as a Means of Information Competence Development // Espacios. 2018. Vol. 39 (Number 33). S. 26. 